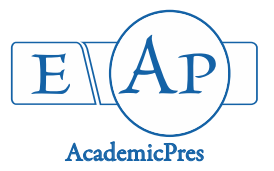

\title{
Total Phenol Content and Antimicrobial Activity of Lingonberry (Vaccinium vitis-idaea L.) from Several Areas in the Eastern Carpathians

\author{
Éva LASLO ${ }^{1}$, Zoltán Attila KÖBÖLKUTI ${ }^{2 *}$
}

\author{
${ }^{1}$ Sapientia Hungarian University of Transylvania, Faculty of Economics, Socio-Human Sciences and Engineering, \\ Department of Bioengeneering, 530104 Miercurea Ciuc, 1 Libertății, Romania; lasloeva@yahoo.com \\ ${ }^{2}$ Szent István University, Faculty of Horticultural Science, Department of Botany and Soroksár Botanical Garden, \\ 1118 Budapest, 29-43 Villányi Street, Hungary; zoltanattila.kobolkuti@gmail.com ("corresponding author)
}

\begin{abstract}
This study evaluated the antimicrobial activity and the total phenol content of Vaccinium vitis idaea L. berry fruit from five different localities with distinct growth sites in the Eastern Carpathians. The antibacterial effect of lingonberry was studied on nine selected Gram-positive and negative, foodborne, and illness causing and spoilage bacteria. The total phenol content was estimated by the Folin-Ciocalteu method. The present results showed stronger antibacterial effect of lingonberry on Gramnegative bacteria, especially on Pseudomonas fluorescens and Pseudomonas aeruginosa. The total phenol content varied between 3.72 and $2.1 \mathrm{mM} \mathrm{GAE} / \mathrm{ml}$. As data suggested, Vaccinium vitis-idaea fruits originating from different geographic regions and environment, differ from each other in terms of bioactive compound quantity and activity. In the selection of new perspective cultivars of lingonberry, the geographical origin of fruits must be considered. Two Step Cluster analysis detected relatively well supported relationship between samples provided from similar growth sites. Correlation analysis showed no correlation between altitude, phenol content and antimicrobial activity.
\end{abstract}

Keywords: antibacterial effect, lingonberry, total phenolics, Vaccinium vitis-idaea

\section{Introduction}

Lingonberry fruit (Vaccinium vitis idaea L.) is an important berry crop harvested from the wild throughout its distribution in northern regions of the world. Throughout history, it has been used as a supplier of energy and vitamins, confering health benefits. It's fruit differs from most of the other wild berry species in long term storage potential. This storage ability depends primarily on their benzoic acid content, with up to 65 mg of benzoic acid per $100 \mathrm{~g}$ of berries (Hjalmarsson and Ortiz, 2001). Several studies have shown that it is a rich source of bioactive compounds, and the interest with regard to its composition has been intensified due to the increased awareness of possible positive health benefits (Gündüz, 2013). The chemical constituents have been well documented. It is rich in fibre, vitamins, minerals, in various phenolic compounds and organic acids. Lingonberry provides significant health benefits due to it's bioactive composition. Phenolic compounds, which are secondary metabolites present in all higher plants, act as defence compounds against plant pathogens (Burdulis et al., 2009) and their production is often induced as a response to various stress conditions. The chemical substituents of Vaccinium vitis idaea L. show antioxidative, antibacterial, anti-inflammatory, antitumor, antiviral, vasoprotective and antifungal activities (Negi, 2012; $\mathrm{Su}, 2012$ ). Flavonoids, phenolic acids, lignans and complex phenolic polymers (polymeric tannins) are the typical substituents, which are rich sources of flavonoids, such as flavonols. Kylli et al. (2011) considered, that the main phenolic compounds in lingonberry are proanthocyanidins, comprising 63-71\% of the total phenolic content. According to the results of Makkar et al. (2009) the most important secondary metabolites of lingonberry are: $63.2 \mathrm{~g} / \mathrm{kg}$ dry matter crude protein, $33.3 \mathrm{~g} / \mathrm{kg}$ dry matter ether extract, $476.1 \mathrm{~g} / \mathrm{kg}$ dry matter neutral detergent fibre, $354.1 \mathrm{~g} / \mathrm{kg}$ dry matter acid detergent fibre, $243.3 \mathrm{~g} / \mathrm{kg}$ dry matter total phenols, $149.2 \mathrm{~g} / \mathrm{kg}$ dry matter total tannins, $174.5 \mathrm{~g} / \mathrm{kg}$ dry matter condensed tannins, $96.3 \mathrm{~g} / \mathrm{kg}$ dry matter tannin activity; percents increase in gas on addition of polyethylene glycol. In fact, wild berries contain more flavonols than many vegetables and fruits commonly used (Puupponen-Pimiä et al., 2005). Anthocyanins (anthocyanidin glycosides) are the predominating group of flavonoids (up to 2,000-5,000 mg/kg fresh weight) (Määttä et al., 2001). More simple phenolic acids, such as hydroxycinnamic acids and hydroxybenzoic acids, are also common (Herrmann, 1989). Chlorogenic acid, which is an ester 
78

between caffeic acid and quinic acid, is a commonly occurring compound. Lingonberry also contains condensed tannins, called proanthocyanidins (Chung et al., 1998). It is rich in diphenolic compounds called lignans $(10-15 \mathrm{mg} / \mathrm{kg}$ dry weight (Mazur et al., 2000), whereas more than 116 anthocyanins and flavonoids compounds have been isolated and identified primarily from the fruits or leaves (Kalt et al., 2008; Su, 2012). Rimando et al. (2004) detected pterostilbene, piceatannol and resveratrol in an amount of 5,884 ng/g dry sample. Ek et al. (2006) identified a total of 28 phenolic compounds, including flavonols, anthocyanidins, catechins and their glycosides. The leaf volatiles of lingonberry have been analyzed by Radulovic et al. (2010), who identified 187 terpenoids, the major contributors being $\alpha$-terpineol (17.0\%), pentacosane (6.4\%), (E, E)- $\alpha$-farnesene (4.9\%), linalool (4.7\%) and (Z)-hex-3-en-1ol (4.4\%). Fatty acid derived compounds (34.1\%) were also identified, while Liu et al. (2014) found arbutin as the major phenolic compound. Organic acid content of Vaccinium vitisidaea was described by Jensen et al. (2002) with a high level of hydrophilic carboxylic acids of $2.27-3.05 \%$ and iridoid glucosides. Szakiel et al. (2012) managed to extract oleanolic and ursolic acid from fruits and leaves of lingonberry. Häkkinen et al. (1999) detected p-coumaric, caffeic, ferulic, phydroxybenzoic, gallic and ellagic acids. The analyses of Radulovic et al. (2010) demonstrated the presence of hexanoic, octanoic, nonanoic and dodecanoic acid and different fatty acid esters. Ek et al. (2006) identified different caffeoyl and ferulic acid conjugates and Kylli et al. (2011) found hydroxycinnamic and hydroxybenzoic acids. The two isomeric acids, oleanolic and ursolic, can be identified as the main triterpenoid constituents in $V$. vitis-idaea. Bere (2007) noticed, that $\mathrm{n}-6$ fatty acids and n-3 fatty acids were present in lingonberry, in 0.14 respectively $0.18 \mathrm{~g} / 100 \mathrm{~g}$ concentration. According to Viljakainen et al. (2003), the main acids of the northern region wild-berry juices are citric and malic acids, while juice of lingonberry contain benzoic acid in amount of 0.1-0.7 g/l. In case of lingonberry, it is the benzoic acid concentration which is especially high (up to $1.3 \mathrm{~g} / \mathrm{l}$ free benzoic acid) and the $\mathrm{pH}$ is very low $(\mathrm{pH}$ 2.6-2.9). Thus, evaluating the antimicrobial efficacy of phenolic compounds either in food matrices or in human body, $\mathrm{pH}$ was a very important parameter to be considered (Puupponen-Pimiä, 2005). It was demonstrated that lingonberry may affect the activity of several human pathogenic and food spoilage bacteria (Caillet et al., 2012). Several studies have demonstrated that this berry fruit possesses a high antimicrobial activity (Lehtonen et al., 2013). Geoghegan et al. (2010) demonstrated the inhibitory effect of quercetin from lingonberry against Actinobacillus actinomycetemcomitans and Porphyromonas gingivalis. According to the results of Türi et al. (1999), aqueous extracts from the fruit contain substances enhancing the aggregation of E. coli. V. vitis- idaea extracts can cause $50 \%$ decrease in E. coli viability (Samoilova et al., 2014) with a high growth-inhibitory effect (Wojnicz et al., 2012). Vamanu et al. (2013) showed that $V$. vitis idaea's tincture was effective against potentially pathogenic strains, such as E. coli, Staphylococcus aureus, Pseudomonas aeruginosa, Candida strains, Listeria strains and Bacillus cereus. Phenolic acids potentially act as metabolic inhibitors of proline in Listeria monocytogenes (Lacombe, 2010).

In the current study, the first specific objective was to investigate the antimicrobial activity of lingonberry fruits against some Gram-positive and Gram-negative foodborne, illness causing and spoilage bacteria: Escherichia coli, Bacillus subtilis, Bacillus cereus, Pseudomonas aeruginosa, Pseudomonas fluorescens, Listeria monocitogenes S1, Listeria monocitogenes S2, Serratia marcescens and Staphylococcus aureus. The second main goal was to determine the total phenolic content of lingonberry samples using different growth site origin (5 locations in the Eastern Carpathians).

\section{Materials and Methods}

\section{Study sites}

Lingonberry samples from 5 locations in the Eastern Carpathians were collected between $18^{\text {th }}$ and $23^{\text {rd }}$ of August 2013. All these locations are within the natural range of the species and can be characterized as habitat types like peat bogs, pine forests and alpine meadows. The sample collection sites are illustrated in Fig. 1 and the geographic coordinates are summarized in Table 1.

\section{Samplingdesign}

Berries in consumption maturity were picked from five different locations of Eastern Carpathians. The sampling sites were chosen by the type of the habitat. The growth sites differed considerably in environmental conditions such as humidity, light exposure, surrounding vegetation, soil type and altitude. The environmental conditions of the peat bog in

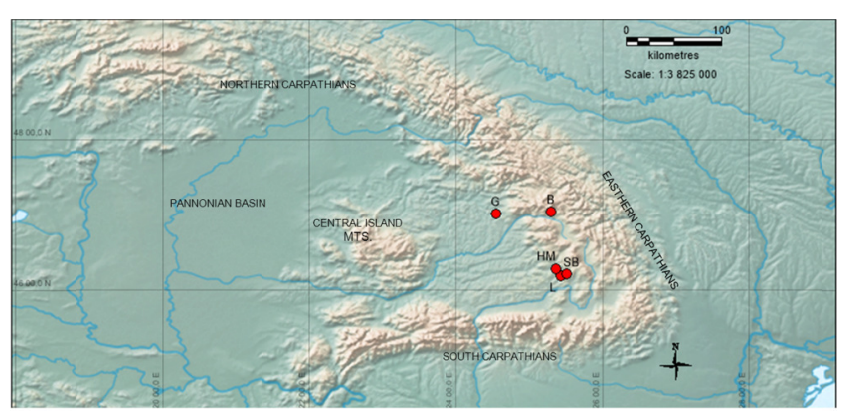

Fig. 1. The lingonberry sample collection sites: L- Tinovul Luci; HM - Harghita-Mădăras; SB - Sântimbru Băi; G Gălăoaia; B - Bilbor

Table 1. List of Vaccinium vitis idaea samples populations from the Eastern Carpathians

\begin{tabular}{|c|c|c|c|c|c|c|c|}
\hline No. & Code & Country & Residential area & Latitude (N) & Longitude $(\mathrm{E})$ & Altitude (m) & Habitat type \\
\hline$\overline{1}$ & $\mathrm{~L}$ & $\mathrm{RO}$ & Tinovul Luci & 46.18 & 25.43 & 1083 & peat bog \\
\hline 2 & $\mathrm{HM}$ & $\mathrm{RO}$ & Harghita-Mădăras & 46.27 & 25.36 & 1681 & alpine meadow \\
\hline 3 & SB & $\mathrm{RO}$ & Sântimbru Băi & 46.21 & 25.51 & 1250 & alpine meadow \\
\hline 4 & G & $\mathrm{RO}$ & Gălăoaia & 47.01 & 24.54 & $\mathbb{1 3 8 1}$ & edge of pine forest \\
\hline 5 & B & $\mathrm{RO}$ & Bilbor & 47.03 & 25.29 & 1173 & edge of pine forest \\
\hline
\end{tabular}


Tinovul Luci were the following: humid microclimate, dense and homogeneous woody crops, and middle shadow. On the alpine meadows at Sântimbru Băi and Harghita-Mădăras's alpine meadow there were sunny hillside, wind exposure and low humidity, whilst the residential area of the population in Gălăoaia and Bilbor can be characterized as a wind protected, sunny hillside with scattered woody vegetation. In Tinovul Luci's peat bog, samples were collected from 4 points with homogenous edaphic conditions, with a distance of about three kilometres between one from another: the first from the edge of the peat bog, the second from nearby the Kormos creek, the third from the edge of the Betula nana population situated in the peat bog, and the fourth sampling point was located east from the previous ones. From the manually collected lingonberries $200 \mathrm{~g}$ samples were weighted and stored in PE bags. Unlike the others, the samples from Harghita-Mădăras (HM) were stored in a water filled recipient. At the end of each collection day, samples were cooled at $5^{\circ} \mathrm{C}$. In the laboratory, all the samples were frozen and stored at $-20^{\circ} \mathrm{C}$ until the analysis.

\section{Sample preparation}

In parallel 2.2 grams of the defrosted berries were measured in two Eppendorf tube, homogenized in a blender, centrifuged at $14,000 \mathrm{rpm}$ for $10 \mathrm{~min}$. During the experiments, the resulted supernatant was used.

\section{Antibacterial activity}

To determine the antibacterial effect, a number of nine Gram-positive and Gram-negative foodborne, illness causing and spoilage bacterial strains were selected. These bacterial strains were: Pseudomonas aeruginosa, Escherichia coli, Staphylococcus aureus, Bacillus cereus, Serratia marcescens, Bacillus subtilis, Pseudomonas fluorescens, Listeria monocytogenes $S 1$ and Listeria monocytogenes S2. The bacterial cultures were grown $24 \mathrm{~h}$ at $28^{\circ} \mathrm{C}$ and respectivelly $37^{\circ} \mathrm{C}$ on Nutrient and TSB agar. $0.1 \mathrm{ml}$ bacterial suspension with 0.5 turbidity in physiological solution was spread in case of each bacteria with surface streaking on Nutrient agar (meat extract 1 g, yeast extract $2 \mathrm{~g}$, peptone $5 \mathrm{~g}, \mathrm{NaCl} 5 \mathrm{~g}$ agar $15 \mathrm{~g}$, distilled water $1,000 \mathrm{ml}$ ) and TSB agar (casein $17 \mathrm{~g}$, peptone from soybean 3 g, $\mathrm{NaCl} 5 \mathrm{~g}$, dipotassium phosphate $2.5 \mathrm{~g}$, glucose $2.5 \mathrm{~g}$, agar $20 \mathrm{~g}$, distilled water $1,000 \mathrm{ml}$ ) plates. In centre of all inoculated mediums a $8 \mathrm{~mm}$ diameter hole was cut with the help of a sterile test-tube. In the hole, $0.05 \mathrm{ml}$ of lingonberry supernatant was dropped. The incubation was realized at $37^{\circ} \mathrm{C}$ in the case of Pseudomonas aeruginosa, Escherichia coli, Staphylococcus aureus at Petri dishes inoculated at $28^{\circ} \mathrm{C}$ with Bacillus cereus, Serratia marcescens, Bacillus subtilis, Pseudomonas fluorescens, Listeria monocytogenes S1, Listeria monocytogenes S2. The inhibitory area dimension was measured. The antibacterial effect of lingonberry samples were expressed in accordance with the size of the inhibition zone. For Listeria monocytogenes species the TSB agar was used.

\section{Determination of the total phenol content}

The total phenol content of the lingonberry samples was determined using the gallic acid equivalence method (GAE). The principle of the method is that the reagent and the phenols hydroxid group form a blue coloured complex and the absorbance of the solution is proportional with the phenol content of the sample (Singleton et al., 1999). To $100 \mu \mathrm{l}$ supernatant $5 \mathrm{ml}$ ultrapure water, $500 \mu \mathrm{l}$ Folin-Ciocalteau reagent and $1.5 \mathrm{ml}$ of $20 \%$ sodium carbonate solution was added, with a parallel reagent blank preparation. The resulting extract was incubated at $40{ }^{\circ} \mathrm{C}$ for 30 minutes. After incubation, the absorbance on $765 \mathrm{~nm}$ was measured. The phenol content - gallic acid equivalence was determined using a calibration curve. The total phenol content of the samples was determined using a calibration line equation and expressed in $\mathrm{mM}$ gallic acid $/ \mathrm{ml}$.

\section{Data analysis}

Correlation-analysis was used to detect relationship between variables: altitude and phenol content and antimicrobial effect in light of phenol content. Two-Step Cluster analysis was performed to reveal natural groupings of samples within the dataset that would otherwise not be apparent.

\section{Results}

\section{Antibacterial effect}

The effects of the lingonberry extracts separately on Grampositive and Gram-negative bacteria are shown in Tables 2 and 3.

The analyzed lingonberry samples showed bacteriostatic effect against the studied bacterial strains. On Gram-positive bacteria, the most inhibitory effect was detected at Staphylococcus aureus, with a large inhibition zone of 26.68 $\pm 4.82 \mathrm{~mm}$, using the L2 sample.

For the two Bacillus strains, the inhibition zone varied between $20.51 \pm 1.28-15.34 \pm 0.45$ (B. cereus) and $18.25 \pm$ $0.74-12.41 \pm 0.85$ (B. subtilis). In both cases, the most effective samples were the SB and L1. A slight bacteriostatic effect was shown at HM samples. The two Listeria monocytogenes strains were slightly inhibited by the HM (Listeria monocytogenes $S 2$ inhibition zone $11.41 \pm 0$, Listeria monocytogenes S1 9.4 \pm 0 ) and the most effective antibacterial effect was observed in the case of L2 sample of Listeria monocytogenes S2 (18.86 \pm 1.05$)$ and SB sample of Listeria monocytogenes S1 (14.84 \pm 0.11$)$.

The antibacterial effect against Gram-negative bacteria was the most promising. The largest inhibitory zones were observed on the two Pseudomonas species. On the studied Pseudomonas fluorescens the measured inhibition zones varied between 21.58 $\pm 0.46 \mathrm{~mm}$ (L2 lingonberry sample), $-30.33 \pm 0.1 \mathrm{~mm}$ (L4 lingonberry sample). The inhibition zone dimensions were $22.85 \pm 0.88 \mathrm{~mm}$ (L2 sample) and $36.42 \pm 4.18 \mathrm{~mm}$ (L4 sample). In both cases, the most effective activity was detected on L4 sample.

Inhibition zone diameter $(\mathrm{mm})$ varied between $12.33 \pm 0$ (HM)-17.66 \pm 0,17 MM (L2) on the assayed Escherichia coli. Regarding the food spoilage bacteria Serratia marcescens, the determined inhibition zone diameter varied between $9.84 \pm 0$ $\mathrm{mm}(\mathrm{HM})$ and $16.37 \pm 1.95 \mathrm{~mm}$ (L2).

\section{Totalphenol content}

The total phenol content varied between 3.72 and 2.1 $\mathrm{mM} / \mathrm{ml}$ (Table 4). The highest values were found in the case of sample L2. The highest phenol content was determined on L2 lingonberry sample collected from Tinovul Luci, near the 
Table 2. Antimicrobial effect of lingonberry samples on Gram-positive bacteria

\begin{tabular}{|c|c|c|c|c|c|}
\hline \multirow{2}{*}{$\begin{array}{l}\text { Lingonberry sample } \\
\text { code }\end{array}$} & Bacillus cereus & Bacillus subtilis & $\begin{array}{c}\text { Listeria monocytogenes } \\
\text { S2 }\end{array}$ & $\begin{array}{c}\text { Listeria monocytogenes } \\
\text { S1 }\end{array}$ & Staphylococcus aureus \\
\hline & \multicolumn{5}{|c|}{ Inhibition zone diameter $(\mathrm{mm}) \pm S D$} \\
\hline $\mathrm{L1}$ & $18.41 \pm 0.56$ & $18.25 \pm 0.74$ & $13.88 \pm 2.85$ & $12.14 \pm 0.58$ & $20.61 \pm 4.75$ \\
\hline L2 & $18.3 \pm 0.63$ & $16.12 \pm 1.21$ & $18.86 \pm 1.05$ & $12.06 \pm 0.7$ & $26.68 \pm 4.82$ \\
\hline L3 & $17.06 \pm 1.54$ & $16.59 \pm 1.04$ & $12.61 \pm 0.39$ & $11.76 \pm 1.28$ & $19.73 \pm 4.89$ \\
\hline L4 & $19.27 \pm 0.14$ & $16.99 \pm 0.96$ & $16.35 \pm 0$ & $10.9 \pm 0.87$ & $18.9 \pm 1.71$ \\
\hline G & $18.25 \pm 0.1$ & $15.54 \pm 0.41$ & $13.08 \pm 2.83$ & $12.95 \pm 0$ & $16.89 \pm 3.57$ \\
\hline HM & $15.34 \pm 0.45$ & $12.41 \pm 0.85$ & $11.41 \pm 0$ & $9.4 \pm 0$ & $16.6 \pm 2.21$ \\
\hline B & $18.72 \pm 0.86$ & $16.89 \pm 0.27$ & $14.08 \pm 2.3$ & $13.83 \pm 0.54$ & $18.02 \pm 3.64$ \\
\hline SB & $20.51 \pm 1.28$ & $18.17 \pm 0.7$ & $13.9 \pm 2.49$ & $14.84 \pm 0.11$ & $19.89 \pm 3.62$ \\
\hline
\end{tabular}

Table 3. Antimicrobial effect of Vaccinium vitis idaea L. samples on Gram-negative bacteria

\begin{tabular}{|c|c|c|c|c|}
\hline \multirow{2}{*}{$\begin{array}{l}\text { Lingonberry sample } \\
\text { code }\end{array}$} & Serratia marcescens & Escherichia coli & Pseudomonas fluorescens & Pseudomonas aeruginosa \\
\hline & \multicolumn{4}{|c|}{ Inhibition zone diameter $(\mathrm{mm}) \pm \mathrm{SD}$} \\
\hline L1 & $13.1 \pm 0.53$ & $13.97 \pm 2.53$ & $30.09 \pm 0.23$ & $34.06 \pm 1.72$ \\
\hline L2 & $16.37 \pm 1.95$ & $17.66 \pm 0.17$ & $21.58 \pm 0.46$ & $22.85 \pm 0.88$ \\
\hline L3 & $11.17 \pm 2$ & $15.06 \pm 1.06$ & $27.05 \pm 0.84$ & $33.78 \pm 1.09$ \\
\hline L4 & $14.43 \pm 0.52$ & $16.21 \pm 0$ & $30.33 \pm 0.1$ & $36.42 \pm 4.18$ \\
\hline G & $13.79 \pm 0.69$ & $15.79 \pm 0$ & $22.32 \pm 0.96$ & $35.21 \pm 3.04$ \\
\hline HM & $9.84 \pm 0$ & $12.33 \pm 0$ & $24.26 \pm 6.2$ & $33.98 \pm 0.27$ \\
\hline B & $13.32 \pm 1.8$ & $12.83 \pm 1.16$ & $22.55 \pm 1.47$ & $33.27 \pm 1.64$ \\
\hline SB & $12.3 \pm 0.65$ & $15.32 \pm 3.09$ & $27 \pm 0.1$ & $34.71 \pm 0.22$ \\
\hline
\end{tabular}

Note: L- Tinovul Luci; HM - Harghita-Mădăras; SB - Sântimbru Băi; G - Gălăoaia; B - Bilbor (the site origin in the Eastern Carpathians of lingonberry).

Table 4. Total phenol content of the studied lingonberry samples with Eastern Carpathian provenience and from different habitat types ( $L$ 1, 2 , 3, 4-peat bog; HM, SB- alpine meadow; B, G pine forest)

\begin{tabular}{ccc}
\hline Code & $\begin{array}{c}\text { Absorbance at } \\
765 \mathrm{~nm} \pm \text { SD }\end{array}$ & $\begin{array}{c}\text { Total phenol content } \\
(\mathrm{mMgallic} \text { acid/ml })\end{array}$ \\
\hline B & $0.126 \pm 0.07274$ & 2.8597 \\
HM & $0.10185 \pm 0.01005$ & 2.3133 \\
SB & $0.14825 \pm 0.00015$ & 3.3631 \\
G & $0.10815 \pm 0.00765$ & 2.4559 \\
L4 & $0.10865 \pm 0.00035$ & 2.4672 \\
L3 & $0.09245 \pm 0.00505$ & 2.1007 \\
L2 & $0.1641 \pm 0.0005$ & 3.7217 \\
L1 & $0.1411 \pm 0.0083$ & 3.2013 \\
\hline
\end{tabular}

Kormos creek, $3.7217 \mathrm{mM} / \mathrm{ml}$. The minimum value was detected in the case of L3 sample, with $2.1007 \mathrm{mM} / \mathrm{ml}$, which originated also from peat bog, on the edge of the Betula nana population.

\section{Cluster analysis}

A dendrogram obtained with IBM SPSS 20.0 Two Step Cluster analysis is presented in Fig. 2. Within the dendrogram using Ward Linkage, samples from Gălăoaia (G) and Bilbor (B) belonging to different sites but with similar type of habitat formed one subcluster and showed a relatively well supported relationship with the sample from Sântimbru băi $(\mathrm{SB})$. The four samples from Tinovul Luci (L1, L2, L3, L4) provenience formed a well supported and separated cluster with a separate subcluster in case of L1 and L4 and in the same group with L3, yet L 2 could be characterised by a completely distant position.

\section{Correlation analysis}

Using each variable and defining correlation as significant at the 0.01 and 0.05 levels, specific data were obtained as presented in Table 5.

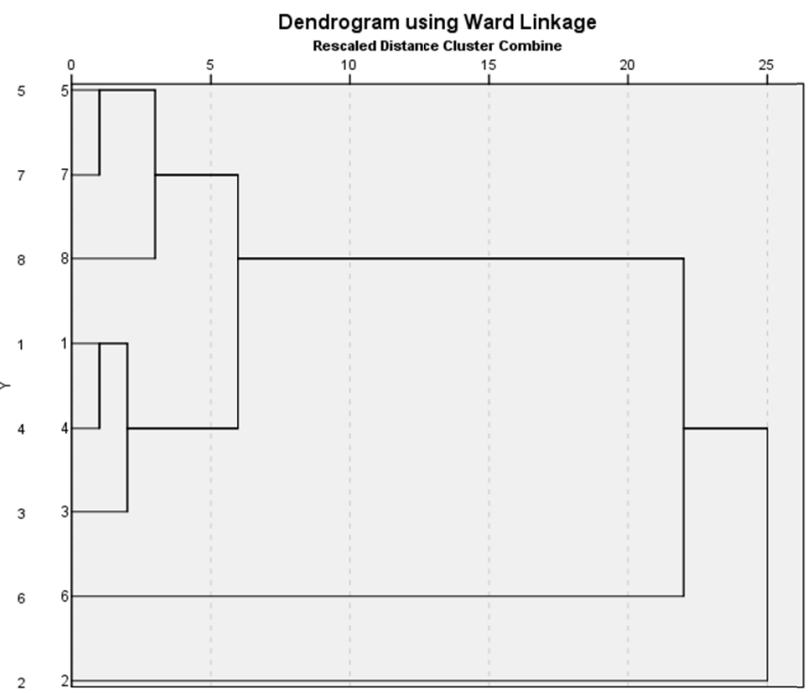

Fig. 2. Dendrogram generated with IBM SPSS 20.0 using Ward Linkage among eight Vaccinium vitis idaea L. samples with 5 different Eastern Carpathian provenience (1, 2, 3, 4Tinovul Luci; 5-Gălăoaia; 6-Harghita-Mădăras; 7-Bilbor; 8Sântimbru Băi; the site origin in the Eastern Carpathians of lingonberry)

The outcome of correlation analysis showed a strong correlation between antimicrobial effects of the samples against Bacillus cereus and Bacillus subtilis, Listeria monocytogenes S1 and Serratia marcescens, Pseudomonas aeruginosa and Staphylococcus aureus.

Significant values have been found between the effect on Listeria monocytogenes $S 2$ and Bacillus cereus, Listeria monocytogenes $S 1$ and E. coli, E. coli and Serratia marcescens. The phenol content was not significantly correlative with altitude or antimicrobial activity. 
Table 5. Correlation between each lingonberry sample obtained data: antimicrobial effect on different bacteria, phenol content and altitude; strong correlation is presented in bold, significant values in italics

Correlations

\begin{tabular}{|c|c|c|c|c|c|c|c|c|c|c|c|}
\hline & B. cereus & B. subtilis & E. coli & $\begin{array}{c}\text { Listeria } \\
m . S I\end{array}$ & $\begin{array}{c}\text { Listeria } \\
\text { m. S2 }\end{array}$ & $\begin{array}{c}\text { Pseud. } \\
\text { aero. }\end{array}$ & $\begin{array}{l}\text { Pseud. } \\
\text { fluor. }\end{array}$ & $\begin{array}{c}\text { Serratia } \\
m .\end{array}$ & St. aureus & $\begin{array}{l}\text { Phenol } \\
\text { content }\end{array}$ & Altitude \\
\hline B. cereus & 1 &, 836 &, 453 &, 468 &, $781^{\circ}$ & ,075 & ,249 &, 543 & ,245 & .545 &,- 573 \\
\hline B. subtilis & $836^{* *}$ & 1 & ,328 & 351 & 691 & 079 & ,482 & ,410 &, 330 & ,463 &,$- 825^{*}$ \\
\hline E. coli &, 453 &, 328 & 1 &, $759^{\circ}$ & , 167 &,- 471 &,- 033 &, $751^{\circ}$ & ,669 & 377 &,- 524 \\
\hline Listeria S1 & 468 &, 351 &, $759^{*}$ & 1 & , 117 &,- 685 &,- 088 & ,912" &, $819^{*}$ & 657 &,- 618 \\
\hline Listeria S2 &, $781^{\circ}$ & ,691 &, 167 & ,117 & 1 & 009 &,- 158 & ,278 & ,116 & ,485 &,- 360 \\
\hline Pseud. aer &, 075 & 079 &, 471 &,- 685 & ,009 & 1 &, 543 &,- 560 & -872 &,- 643 & 241 \\
\hline Pseud.fluor. & ,249 & ,482 &, 033 &,- 088 &,- 158 &, 543 & 1 &,- 192 &,- 116 &,- 152 &,- 362 \\
\hline Serratia &, 543 & , 410 &, $751^{\circ}$ &, $912^{* *}$ & 278 &,- 560 &,- 192 & 1 & ,661 & ,605 &,- 602 \\
\hline St. aureus & 245 & 330 &, 669 & $819^{*}$ &, 116 &,$- 872^{* \prime}$ &,- 116 & 661 & 1 &, $750^{\circ}$ &,- 587 \\
\hline Phenol content &, 545 & ,463 & 377 & ,657 & ,485 &,- 643 &,- 152 & ,605 &, $750^{*}$ & 1 &,- 360 \\
\hline Altitude &,- 573 &,$- 825^{\circ}$ &, 524 &,- 618 &,- 360 &, 241 &,- 362 &,- 602 &,- 587 &,- 360 & 1 \\
\hline
\end{tabular}

*. Correlation is significant at the 0.05 level (2-tailed).

\section{Discussion}

Lingonberry fruits, due to their bioactive compounds, are reported to possess potential health-promoting effects and bactericide effects. The results showed that the assayed bacterial species exhibit different sensitivities. In addition, the same bacterial strains showed differences in sensitivity toward fruit samples with different origin. According to Paudel et al. (2014) in a brine shrimp toxicity test, lingonberry showed $4.7 \pm 0.19$ PH-IC50 $(\mu \mathrm{g} / \mathrm{mL}), 8.5 \pm 0,51 \mathrm{~mm}$ inhibition zone against Staphylococcus aureus. Polymeric proanthocyanidin extracts of lingonberries have strong antimicrobial effect against Staphylococcus aureus (Kylli et al., 2011). Myricetin inhibits the growth of all lactic acid bacteria derived from the human gastrointestinal tract flora (Puupponen-Pimiä et al., 2001). Some authors consider that tannins from $V$. vitis-idaea L. could potentially be used against Actinobacillus actinomycetemcomitans, Porphyromonas gingivalis and Prevotella intermedia, which are selected periodontal pathogens (Ho et al., 2010). The antimicrobial activity of lingonberry against two other oral pathogens, Streptococcus mutans and Fusobacterium nucleatum was evaluated by Riihinen et al. (2014), the antimicrobial activity against planctonic cells being associated with both the polymeric and A-type lingonberry procyanidins.

In contrast with the present results, lingonberry is considered to have slight antimicrobial activity against Bacillus subtilis and Micrococcus luteus (Rauha et al., 2000). According to Nohynek et al. (2006), lingonberry phenolics have strong antimicrobial activity against Bacillus cereus, Staphylococcus epidermidis as detected in this study too. Due to the results of Huttunen et al. (2013), 60\% and 40\% concentrations of the lingonberry honey have antimicrobial effect against $S$. pneumoniae, S. pyogenes $(\mathrm{p}<0.01)$ and inhibit the growth of $S$. aureus ( $\mathrm{p}<0.01$ ) with bacterial survival of $56 \%$. According to Chen et al. (2012) the minimum inhibitory concentration of Vaccinium vitis-idaea extracts against Staphylococcus aureus is $18.75 \mathrm{mg} / \mathrm{ml}$, Escherichia coli $18.75 \mathrm{mg} / \mathrm{ml}$, Enterobacter aerogenes $37.50 \mathrm{mg} / \mathrm{ml}$, Salmonella typhi $37.50 \mathrm{mg} / \mathrm{ml}$, Streptococcus hemolytic $37.50 \mathrm{mg} / \mathrm{ml}$, Shigella sp. $18.75 \mathrm{mg} / \mathrm{ml}$, Bacillus subtilis $18.75 \mathrm{mg} / \mathrm{ml}$. Antibacterial effect against Helicobacter pilori activity was observed in $10 \%$ concentration.
Tannins from Vaccinium vitis-idaea have antibacterial effects against Porpyromonas ginigivalis and Prevotella intermedia (Hayashi et al., 2008), and inhibitory effect against Listonella anguillarum (serotypes $\mathrm{O} 1$ and O2), Yersinia ruckeri, Photobacterium damselae subsp. piscicida and Lactococcus garvieae (Bulfon et al., 2014). Tolmacheva et al. (2014) applied aqueous and ethanolic extracts from Vaccinium vitis idaea in a radial growth inhibition assay against wild-type Chromobacterium violaceum ATCC 31532 and reporter Chromobacterium violaceum NCTC 13274 strains observed a prominent growth-inhibition activity.

The present findings showed that the studied extracts have had stronger effect on Gram-negative bacteria, especially on $P$ seudomonas fluorescens and Pseudomonas aeruginosa, yet not as much on Gram-positive bacteria. According to PuupponenPimiä et al. (2001), these variations may reflect differences in the bacterial cell wall structure. The correlation results showed that the phenol content was not significantly correlative with the antimicrobial activity. Annuk et al. (1999) have studied the antimicrobial activity of aqueous extracts of lingonberry against the Gram-negative pathogen Helicobacter pylori, and concluded that tannic acid seemed to be the responsible component of the previously mentioned fact. Furthermore, Holopainen et al. (1988) related that the activity is known to be due to the arbutin and metylarbutin. Lingonberries are also rich in benzoic acid, a commonly used antimicrobial agent in foods. Häkkinen et al. (1999) showed that the antimicrobial activity of berry extracts against Gram-negative strains are not inhibited by pure phenolic compounds, whereas the inhibitory effects are due to complex phenolic polimers and other bioactive compounds by themselves or in combination with phenols. The antimicrobial effect might be due to the synergism of bioactive compounds and its amount is in correlation with the plant origin and environmental conditions. Several studies have reported the influence of genotype and climatic conditions on total phenolics of different cultivars of Vaccinium species (Connor et al., 2002; Jovancevic et al., 2011). According to those studies, the degree of anthocyanidin accumulation does not primarily depend on the light conditions, but on a favourable impact of low temperatures and a limiting effect of high temperatures. In the present research, the total phenol content was higher in the case of SB, B, L1 and L2 samples. 
82

During fruit collection at Sântimbru Băi (SB), HarghitaMădăras (HM) and Bilbor (B) it has been observed a sunny environment, also in case of the L1 sampling point, which was on the edge of a peatbog, with sparse canopy where ripening fruits receive greater amount of solar radiation. However, this study noted lower phenol content on the HM samples originating from quite a similar environment. The low content of phenols in the case of the HM sample can be explained by the different storage method and the late ripening period determined by the high altitude. As the results of the Cluster analysis show, dendrogram samples from Gălăoaia $(G)$ and Bilbor (B), which belong to different populations but have a similar type of habitat, form one subcluster and show a relatively well supported relationship with the sample from Sântimbru Băi (SB). In the same way, three samples from Tinovul Luci (L1, L3, L4) form a well supported and separated group. As data suggests, Vaccinium vitis-idaea fruits originating from different geographic regions and environment differ from each other in terms of bioactive compounds, in quantity and activity.

In the selection of new perspective cultivars of lingonberry, the geographical origin of fruits must be considered. The L2 sample, which was gathered from the same peatbog as the L1, L3 and L4 samples, can be characterized by humid microclimate, dense canopy, penumbra and highly acidic soil. Unlike the previous ones, the L2 sample had a completely distant position in the dendrogram. However, taking into account also that the L2 sample was collected from near a creek, which can be a geographic barrier into the clonal spread of the species, this may indicate the presence of a different genotype in Tinovul Luci (L) population, which give reason to additional genetic analyses.

\section{Conclusions}

The results of this study showed stronger antibacterial effect of lingonberry samples on Gram-negative bacteria, especially on Pseudomonas fluorescens and Pseudomonas aeruginosa. The growth of the studied foodborne, illness causing and spoilage bacterial strains, was also affected by the analysed lingonberry samples. The results confirm that the Vaccinium vitis idaea berry fruits belonging to different growing sites differ from each other in terms of bioactive compounds in quantity and activity.

\section{References}

Annuk H, Hirmo S, Turi E, Mikelsaar M, Arak E, Wadström T (1999). Effect on cell surface hydrophobicity and susceptibility of Helicobacter pylorii to medicinal plant extracts. FEMS Microbiology Letters 172:41-45.

Bere E (2007). Wild berries: a good source of omega-3. European Journal of Clinical Nutrition 61(3):431-433.

Bulfon, C, Volpatti D, Galeotti M (2014.) In vitro antibacterial activity of plant ethanolic extracts against fish pathogens. Journal of the World Aquaculture Society 45(5):545-557.

Burdulis D, Äarkinas A, Jasutien I, Stackevi E, Nikolajevas L, Janulis V (2009). Comparative study of anthocyanin composition, antimicrobial and antioxidant activity in bilberry (Vaccinium myrtillus L.) and blueberry (Vaccinium corymbosum L.) fruits. Acta Poloniae
Pharmaceutica and Drug Research 66:399-408.

Caillet S, Côté J, Sylvain J-F, Lacroix M (2012). Antimicrobial effects of fractions from cranberry products on the growth of seven pathogenic bacteria. Food Control 23:419-428.

Chen S, Luo QS, Zhang FY (2012). Study on antimicrobial properties and stability of extracts from berries. Science and Technology of Food Industry 9:31.

Chung K-T, Lu Z, Chou MW (1998). Mechanism of inhibition of tannic acid and related compounds on the growth of intestinal bacteria. Food and Chemical Toxicology 36:1053-1060.

Connor AM, Luby JJ, Tong CB, Finn CE, Hancock JF (2002). Genotypic and environmental variation in antioxidant activity, total phenolic content, and anthocyanin content among blueberry cultivars. Journal of the American Society for Horticultural Science 127(1):89-97.

Ek S, Kartimo H, Matrila S, Tolonen A (2006). Characterization of phenolic compounds from lingonberry (Vaccinium vitis-idaea). Journal of Agricultural and Food Chemistry $54(26): 98349842$.

Geoghegan, F, Wong RWK, Rabie ABM (2010). Inhibitory effect of quercetin on periodontal pathogens in vitro. Phytotherapy Research Volume 24(6):817-820.

Gündüz GT (2013). Antimicrobial activity of sloe berry purees on Salmonella spp. Food control 32(2):354358.

Häkkinen SH, KärenlampiSO, Heinonen IM, Mykkänen HM, Törrönen AR (1999). Content of the Flavonols Quercetin, Myricetin, and Kaempferol in 25 Edible Berries. Journal of Agriculture and Food Chemistry 47(6):22742279.

Häkkinen S, Heinonen M, Kärenlampi S, Mykkänen H, Ruuskanen J, Törrönen R (1999). Screening of selected flavonoids and phenolic acids in 19 berries. Food Research International 32(5):345-353.

HayashI S, Funatogawa K, Yoshikazu H (2008). Antibacterial effects of tannins in childrens and adults. Botanical medicine in clinical practice. CABI 141-151.

Herrmann K (1989). Occurence and content of hydroxycinnamic and hydroxybenzoic acid compounds in foods. Critical Reviews in Food Science and Nutrition 28:315-347.

Hjalmarsson I, Ortiz R (2001). Lingonberry: Botany and horticulture. Horticultural Reviews 27:79-123.

Ho KY, Tsai, CC, Huang JS, Chen CP, Lin TC, Lin CC (2001). Antimicrobial activity of tannin components from Vacinium vitis-idaea L.Journal of Pharmacy and Pharmacology 53(2):1687-191.

Holopainen M, Jahodár L, Seppänen-Laakso T, Laakso I, Kauppinen V (1988). Antimicrobial activity of some Finnish Ericaceous plants. Acta PharmaceuticaFennica 97:197-202.

Huttunen S, Riihinen K, Kauhanen J, Tikkanen-Kaukanen C (2013). Antimicrobial activity of different Finnish monofloral honeys against human pathogenic bacteria. APMIS 121(9):827-834.

Jensen HD, Krogfelt KA, Cornett C, Hansen SH, Christensen, SB (2002). Hydrophilic carboxylic acids and iridoid glycosides in the juice of American and European cranberries (Vacinium macrocarpon and $V$. oxycoccos), lingonberries (V. vitis-idaea), and blueberries (V. myrtillus). Journal of Agricultural and Food Chemistry 50(23):6871-6874.

Jovančević M, Balijagić J, Menković N, Scaron K, Zdunić G, Janković T, Dekić-Ivanković M (2011). Analysis of phenolic compounds in wild 
populations of bilberry (Vaccinium myrtillus L) from Montenegro. Journal of Medicinal Plants Research 5(6):910-914.

Kalt W, Mackinnon S, Mcdonald J, Vinqvist M, Craft C, Howell A (2008). Phenolics of Vaccinium berries and other fruit crops, Journal of the Science of Food and Agriculture 88:68-76.

Kylli P, Nohynek L, Puuponen-Pimia R, Westerlund-Wikström B, Leppanen T, Welling J, Moilanen E, Heinonen, M (2011). Lingonberry (Vaccinium vitis-idaea) and european cranberry (Vaccinium microcarpon) Proanthocyanidins: isolation, identification and bioactivities. Journal of Agricultural and Food Chemistry 59(7):3373-3384.

Lacombe AV, Wu CH, Tyler SK, Edwards K (2010). Antimicrobial action of the American cranberry constituents; phenolics, anthocyanins, and organic acids, against Escherichia coli O157:H7, International Journal of Food Microbiology 139:102-107.

Lehtonen H-M, Lindstedt A, Järvinen R, Sinkkonen J, Graça G, Viitanend M,Kallio H, Gil AM (2013). 1HNMR-based metabolic fingerprinting of urine metabolites after consumption of lingonberries (Vaccinium vitisidaea) with a high-fat meal. Food Chemistry 138(2-3):982-990.

Liu P, Lindstedt A, Markkinen N, Sinkkonen J, Suomela JP, YangB (2014). Characterization of metabolite profiles of leaves of bilberry (Vaccinium myrtillus L.) and lingonberry (Vaccinium vitis-idaea L.). Journal of Agricultural and Food Chemistry 62(49):12015-12026.

Määttä K, Kamal-Eldin A, Törrönen R (2001). Phenolic compounds in berries of black, red, green, and white currants (Ribes sp.). Antioxidants and Redox Signaling 3:981-993.

Makkar HPS, Norvsambuu T, Lkhagvatseren S, Becker K (2009). Plant secondary metabolites in some medicinal plants of Mongolia used for enhancinganimal health and production. Tropicultura 27(3):159-167.

Mazur WM, Uehara M, Wähälä K, Adlercreutz H (2000). Phytooestrogen content of berries, and plasma concentrations and urinary excretion of enterolactone after a single strawberry- meal in human subjects. British Journal of Nutrition 83:381-387.

Negi PS (2012). Plant extracts for the control of bacterial growth: Efficacy, stability and safety issues for food application, Journal of International Journal of Food Microbiology 156:7-17.

Nohynek LJ, Alakomi H-L, Kähkönen MP, Heinonen M, Helander IM, Oksman-Caldentey K-M, Puupponen-Pimï RH (2006). Berry phenolics: antimicrobial properties and mechanisms of action against severe human pathogens. Nutrition and Cancer 54(1):18-32.

Paudel B, Bhattarai HD, Kim IC, Lee H, Sofronov R, Ivanova L, Yim JH (2014). Estimation of antioxidant, antimicrobial activity and brine shrimp toxicity of plants collected from Oymyakon region of the Republic of Sakha (Yakutia), Russia. Biological research 47:1-6.

Puupponen-Pimiä R, Nohynek L, Alakomi HL (2005). Bioactive berry compounds-novel tools against human pathogens. Applied Microbiology 67(1):8-18.

Puupponen-Pimi R, Nohynek L, Meier C, Kähkönen M, Heinonen M, Hopia A, Oksman-Caldentey K-M (2001).Antimicrobial properties of phenolic compounds from berries. Journal of Applied Microbiology 90(4):494-507.

Puupponen-Pimia R, Aura AM, Karppinen S, Oksman-Caldentey KM, Poutanen K (2004). Interactions between plant bioactive food ingredients and intestinal flora-effects on human health. Bioscience and Microflora 23(2):67-80.

Puupponen-Pimiä R, Nohynek L, Alakomi HL, Oksman-Caldentey KM (2005). Bioactive berry compounds-novel tools against human pathogens. Applied Microbiology and Biotechnology 67(1):8-18.

Radulović N, Blagojević P, Palić R (2010). Comparative study of the leaf volatiles of Arctostaphylos wva-ursi (L.) Spreng. and Vaccinium vitis-idaea L. (Ericaceae). Molecules 15:6168-6185.

Rauha J-P, Remes S, Heinonen M, Hopia A, Kähkönen M, Kujala T, Pihlaja K, Vuorela H, Vuorela P (2000). Antimicrobial effects of Finnish plant extracts containing flavonoids and other phenolic compounds. International Journal of Food Microbiology 56(1):3-12.

Riihinen KR, Ou YM, Gödecke T, Lankin DC, Pauli GF, Wu CD (2014). The antibiofilm activity of lingonberry flavonoids against oral pathogens is a case connected to residual complexity. Fitoterapia 97:78-86.

Rimando AM, Kal W, Magee JB, Dewey J, Ballington JR (2004). Resveratrol, pterostilbene, and piceatannol in Vaccinium berries. Journal of Agricultural and Food Chemistry 52(15):4713-4719.

Samoilova Z, Muzyka N, Lepekhina E, Oktyabrsky O, Smirnova G (2014). Medicinal plant extracts can variously modify biofilm formation in Escherichia coli. Antonievan Leeuwenhoek 105(4):709-722.

Singleton V L, Orthofer R, Lamuela-Raventos RM (1999). Analysis of total phenols and other oxidation substrates and antioxidants by means of folin-ciocalteu reagent. Methods in Enzymology 299:152-178.

Su Z (2012). Anthocyanins and flavonoids of Vaccinium L. Pharmaceutical Crops 3:7-37.

Szakiel A, Chołuj A, Pączkowski C (2007). Comparison of the content of triterpene acids in edible berries of three wild Vaccinium species occurring in Poland. Acta Biochimica Polonica 54(Suppl4):77.

Szakiel A, Mroczek A (2007). Distribution of triterpene acids and their derivatives in organs of cowberry (Vaccinium vitis-idaea L.) plant. Acta Biochimica Polonica-English edition 54(4):733.

Szakiel A, Pączkowski C, Koivuniemi H, Huttunen S (2012). Comparison of the triterpenoid content of berries and leaves of lingonberry Vaccinium vitis-idaea from Finland and Poland. Journal of Agricultural and Food Chemistry 60(19):49945002.

Tolmacheva AA, Rogozhin EA, Deryabin DG (2014). Antibacterial and quorum sensing regulatory activities of some traditional EasternEuropean medicinal plants. Acta Pharmaceutica 64(2):173-186.

Türi E, Türi M, Annuk H, Arak E (1999). Action of aqueous extracts of bearberry and cowberry leaves and wild camomile and pineapple-weed flowers on Escherichia coli surface structures. Pharmaceutical Biology 37(2):127-133.

Vamanu E, Vamanu A, Dopcea E (2013). In vitro evaluation of antioxidative properties in Capsicum annuum Vaccinium vitis-idaea and Melissa officinalis tinctures. Scientific Bulletin. Series F Biotechnologies 17:99-104.

Viljakainen S (2003). Reduction of acidity in northern region berry juices. $\mathrm{PhD}$ Thesis, Helsinki University of Technology.

Wojnicz DZ, Kucharska AZ, Sokól-Łętowska A, Kicia M, TichaczekGoska D (2012). Medicinal plants extracts affect virulence factors expression and biofilm formation by the uropathogenic Escherichia coli. Urological Research 40(6):683-697. 